\title{
PSYCHOLOGICA
}

\section{Internalizing and externalizing symptoms of crack-cocaine users}

Autor(es): $\quad$ Oliveira, Margareth da Silva; Cerutti, Fernanda; Ribeiro, Fernanda de Almeida; Argimon, Irani Iracema de Lima

Publicado por: Imprensa da Universidade de Coimbra

URL

persistente: URI:http://hdl.handle.net/10316.2/40756

DOI: DOI:https://doi.org/10.14195/1647-8606_59-1_3

Accessed : $\quad$ 26-Apr-2023 14:16:47

A navegação consulta e descarregamento dos títulos inseridos nas Bibliotecas Digitais UC Digitalis, UC Pombalina e UC Impactum, pressupõem a aceitação plena e sem reservas dos Termos e Condições de Uso destas Bibliotecas Digitais, disponíveis em https://digitalis.uc.pt/pt-pt/termos.

Conforme exposto nos referidos Termos e Condições de Uso, o descarregamento de títulos de acesso restrito requer uma licença válida de autorização devendo o utilizador aceder ao(s) documento(s) a partir de um endereço de IP da instituição detentora da supramencionada licença.

Ao utilizador é apenas permitido o descarregamento para uso pessoal, pelo que o emprego do(s) título(s) descarregado(s) para outro fim, designadamente comercial, carece de autorização do respetivo autor ou editor da obra.

Na medida em que todas as obras da UC Digitalis se encontram protegidas pelo Código do Direito de Autor e Direitos Conexos e demais legislação aplicável, toda a cópia, parcial ou total, deste documento, nos casos em que é legalmente admitida, deverá conter ou fazer-se acompanhar por este aviso.

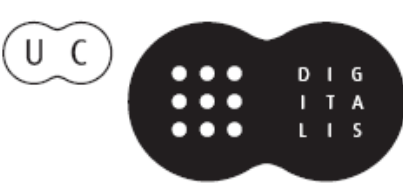


VOLUME 5

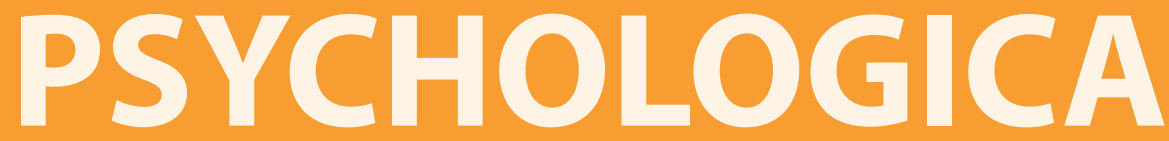

IMPRENSA DA UNIVERSIDADE DE COIMBRA

COIMBRA UNIVERSITY PRESS

FACULDADE DE PSICOLOGIA E DE CIÊNCIAS

DA EDUCAÇÃO DA UNIVERSIDADE DE COIMBRA 


\title{
Internalizing and externalizing symptoms of crack-cocaine users
}

\author{
Margareth da Silva Oliveira ${ }^{1}$, Fernanda Cerutti ${ }^{2}$, Fernanda de Almeida \\ Ribeiro $^{3}$ e Irani Iracema de Lima Argimon ${ }^{4}$
}

\begin{abstract}
The present study aimed to analyse the psychopathological functioning of crack-cocaine users compared to the general population. It is a quantitative cross-sectional study. A sample of 971 adults, aged from 18 to 59 years, was divided in two groups: crack-cocaine users and general population, selected by convenience sampling. Results: Statistical analysis, using Pearson's chi-square test, showed a significant association between crack-cocaine users and a greater severity in internalizing and externalizing symptoms. Binary logistic regression analysis using the conditional stepwise backward method showed a severity model for the use of crack-cocaine adjusted to the gender, age, schooling, and anxiety/ depression symptoms variables. Conclusions: Based on the results, the comorbidities associated with crack-cocaine use should be investigated to ensure an appropriate treatment for these users.
\end{abstract}

Keywords: crack-cocaine; internalizing symptoms; externalizing symptoms

1 Escola das Humanidades, Programa de Pós-Graduação em Psicologia, Pontifícia Universidade Católica do Rio Grande do Sul. Email: marga@pucrs.br

2 Escola das Humanidades, Programa de Pós-Graduação em Psicologia, Pontifícia Universidade Católica do Rio Grande do Sul. Email: fernanda.cerutti@acad.pucrs.br

3 Escola das Humanidades, Programa de Pós-Graduação em Psicologia, Pontifícia Universidade Católica do Rio Grande do Sul. Email: fernandaribeiro66@hotmail.com

4 Escola das Humanidades, Programa de Pós-Graduação em Psicologia, Pontifícia Universidade Católica do Rio Grande do Sul. Email: argimoni@pucrs.br 


\section{Sintomas internalizantes e externalizantes em usuários de cocaína-crack}

\section{Resumo}

O objetivo desse estudo foi analisar o funcionamento psicopatológico de usuários de cocaína-crack em comparação com a população geral. Trata-se de um estudo transversal quantitativo. Amostra de 971 adultos de 18 a 59 anos, divididos em dois grupos: usuários de cocaína-crack e população geral, escolhidos por conveniência. Resultados: A análise estatística de associação, por meio do teste qui-quadrado de Pearson, aponta relação significativa entre os usuários de cocaína-crack e a maior gravidade dos sintomas internalizantes e externalizantes. A análise de regressão logística binária pelo método Backward conditional aponta um modelo de gravidade para o uso de cocaína-crack ajustado com as variáveis sexo, idade, escolaridade e sintomas de ansiedade/depressão. Conclusões: A partir dos resultados encontrados considera-se relevante o estudo das comorbidades do uso de cocaína-crack, visando um tratamento adequado a esses usuários.

Palavras-chave: cocaína-crack; sintomas internalizantes; sintomas externalizantes

\section{INTRODUCTION}

Crack-cocaine use is well-known in Brazil and has occurred for at least three decades, causing many impairments to users and relatives (Ribeiro, Nappo, \& Sanchez, 2012). This perspective is reinforced by a significant rise in the cocaine trading in the last few years in Brazil, when compared to the major cocaine markets in the world (UNODC, 2013). This rise increases the probability of crack-cocaine use, since this cocaine is cheaper for the users. For instance, in 2012, cocaine use among Brazilian adults was 3.8\% for at least one use in life and $1.7 \%$ for use in the previous year. Regarding crack-cocaine, $1.3 \%$ used the drug at least once in life and $0.7 \%$ used the drug in the previous year (Laranjeira, 2014).

These data reveal the need to analyse aspects associated to crack-cocaine use. Thus, once the common risk factors for crack-cocaine users are identified, preventive strategies can be devised and specific interventions performed. The literature addressing this subject has mentioned the importance of studying the psychopathological functioning of crack-cocaine users, understanding how they react emotionally to adversities and difficult situations, and how they externalize their difficulties and feelings, which Achenbach and Rescorla (2003) respectively denominated as internalizing and externalizing symptoms. 
Although studies about crack-cocaine are not recent, we did not find a significant number of studies relating crack-cocaine use with internalizing and externalizing symptoms. Therefore, this review selected studies addressing only cocaine or psychoactive substance use as well. The reason for that is the importance to highlight the impairments caused by these symptoms and the substance use disorder. In a study by Vergara-Moragues et al. (2013), the most prevalent comorbidities found in cocaine users were humour and anxiety disorders. Furthermore, it was observed that psychological disorders hinder the treatment success.

The relationship between substance use disorders with anxiety disorders (Marmorstein, 2012) and humour disorders was found in the literature (Chen et al., 2011; Silva, Kolling, Carvalho, Cunha, \& Kristensen, 2009). Moreover, it was observed that humour disorders (Scheffer, Pasa \& Almeida, 2010) and, more specifically, the major depressive episode (Johnson et al., 2011) might not only share a connection, but also engender a higher risk of crack-cocaine use.

A higher prevalence of aggressive behaviour, an externalizing symptom, was found in inpatients who were admitted for cocaine use (Macdonald, Erickson, Wells, Hathaway, \& Pakula, 2008). Adults who tried crack-cocaine at some point in life had a positive correlation with aggressive episodes at the beginning of adult life (Narvaez et al., 2014).

Based on the aforementioned data, we found that most studies correlated psychopathological comorbidities with substance use disorders whereas some focused specifically the crack-cocaine use. Additionally, some studies investigated the adaptive aspects of this population by qualitative and observational methods. However, these references do not stress the divergence of these characteristics with people who do not use crack-cocaine. Therefore, the present study identified the severity of psychopathological functioning symptoms and compared it to the general population. It specifically aims to design a profile that predicts crack-cocaine use, targeting the psychopathological functioning and socio demographic data.

\section{MATERIAL AND METHODS}

\section{Participants}

The sample comprised 971 adult participants aged from 18 to 59 years, selected by convenience. Most of them were men (63.2\%) and had higher education (49.2\%) and the average age was $31.13(S D=11.18)$. The sample was divided into two groups. 
One group was composed of 407 crack-cocaine users, with an average age of $31.55(S D=9.60)$, most of them men $(87.5 \%)$, with secondary education $(42.3 \%)$. The discrepancy between the percentages of the gender variable (crack-cocaine use is more prevalent among men) is commonly found in the literature (Bastos \& Bertoni, 2014). Therefore, this difference was considered and controlled in statistical analysis. The inclusion criteria were: a) admission in specialized public or private service that attended patients from Porto Alegre and its metropolitan region; b) participation must occur between the $7^{\text {th }}$ and the $15^{\text {th }}$ day after ceasing the substances use; c) at least five years of complete formal education, for the required cognitive abilities; and d) crack-cocaine use reported as the main reason for admission.

The other group was composed of 564 participants from the general population with an average age of $30.84(S D=12.19)$, whereas most of them were women (54.3\%) and had higher education (62.6\%). All of them lived in the state of Rio Grande do Sul, mostly in the metropolitan region of Porto Alegre. Inclusion criteria were: a) adult individuals aged 18-59 years; b) from both genders; c) at least five years of formal education; d) currently not undergoing any kind of psychological or psychiatric treatment; and e) no diagnose of mental disorders.

\section{Measures}

We used the Adult Self-Report (ASR), which is an Achenbach System of EmpiricallyBased Assessment (Aseba) scale, specifically designed for individuals aged from 18 to 59 years old. It's a self-report instrument that assesses adaptive and psychopathological functioning aspects. The respondent rates each item as $0=$ not true; 1 = somewhat or sometimes true; 2 = very true or often true, based on the preceding six months (e.g. "12. Complains of loneliness"; "65. Refuses to talk"; 43. Lying or cheating") (Achenbach \& Rescorla, 2003).

The instrument comprises 126 items, which are split into four great assessment areas composed by subscales. The first great assessment area is defined as scales that assess syndromes, which includes subscales of internalizing and externalizing symptoms. The internalizing symptoms correspond to anxiety/depression, isolation/ depression, and somatic problems, whereas externalizing symptoms comprehend aggressive and intrusive behaviours and rule violation (Achenbach \& Rescorla, 2003).

The second great assessment area is defined as scales that assess the current adaptive functioning, which comprises the family, work, marriage, friendships, education, and general adaptive function subscales. The third great assessment area is defined as scales that assess substance use, which comprises the subscales: tobacco, alcohol, drugs, and the average substance use. The last area of assessment is 
defined as scales that are oriented by the Diagnostic and Statistical Manual of Mental Disorders - DSM, which includes Clinical and Personality Disorders (Achenbach \& Rescorla, 2003). The present study used scales from the first great assessment area.

There are specific cut-off points for each scale, and the scores obtained are classified as normal, borderline, or clinical (Achenbach \& Rescorla, 2003). A study addressed the ASR validity to adapt it to the Brazilian reality. The total sample, composed by 1,444 persons, was divided into three groups (general population, drugs addicts, and persons with clinical or emotional problems). All participants were aged from 18 to 59 years and completed at least five years of formal education. The formal consistency indexes found between the scales ranged from $\alpha=.70$ to $\alpha=.86$ (Lucena-Santos, Moraes, \& Oliveira, 2014).

\section{Procedures}

The research was approved by the Research Ethics Committee of the Pontifícia Universidade Católica do Rio Grande do Sul - PUCRS (09/04941). We ensured confidentiality and anonymity to the participants and the assessment was only performed after their full understanding of the study's objectives. They expressed their acceptance by signing the Free Informed Consent in two copies (one for the participant and another for the researcher).

The data collection occurred throughout the year of 2012. The instrument was applied by psychologists and trained undergraduates. The population of crack-cocaine users was interviewed at outpatient and inpatient facilities that were specialized in treating drug abuse. The general population subjects' recruitment was done at public places, such as universities, or by acquaintances' suggestions.

\section{Data analysis}

At first, the Assessment Data Manager (ADM) software was used to gather the ASR data from the ASEBA scales (Bolsoni-Silva \& Marturano, 2010). Next, the data were exported and assessed by using the Statistical Package for Social Sciences (SPSS) 17.0. Descriptive analysis (frequencies, means and standard deviations), analysis by association using Pearson's chi-square test were performed, considering adjusted residual analysis. A binary logistic regression analysis, using the conditional stepwise backward method, was performed to detect potential predictors of the group of crack-cocaine users. We used the conditional method to ensure homogeneity between groups, since no pairing method was used, considering that the survey 
aimed to search as many effects the drug users' groups were exposed to as possible (Cepeda, Boston, Farrar, \& Strom, 2003; Medronho, 2003).

\section{RESULTS}

Data analysis showed a significant statistical association between the groups (general population and crack-cocaine users) and internalizing symptoms ( $p<$ .001). The general population group was within the normal range: $67.1 \%(n=378)$ regarding internalizing symptoms. In turn, the group of crack-cocaine users was within the borderline range: $19.5 \%(n=79)$ and clinical range: $53.1 \%(n=215)$. According to the linear-by-linear association, the results indicate that the higher the score for internalizing symptoms' severity, the greater the probability of belonging to the crack-cocaine users' group $(p<.001)$.

The statistical association of externalizing symptoms was also significant between the groups $(p<.001)$. The general population group was within normal range: $60.6 \%(n=507)$ and the group of crack-cocaine users was within borderline range: $50 \%(n=26)$ and clinical range: $63.4 \%(n=52)$. Linear-by-linear association indicates that the higher the severity score in externalizing symptoms, the higher the probability of belonging to the crack-cocaine users' group $(p<.001)$.

In order to investigate whether the internalizing and externalizing symptoms could represent the crack-cocaine group, binary logistic regression analysis using the conditional stepwise backward method was implemented and adjusted for the variables gender, age range and schooling. Table 1 presents the results of the binary logistic regression analysis.

Table 1

Model of Severity Crack Use Adjusted with Variables Gender, Age Range, Schooling and Internalizing Symptoms (Anxiety and Depression)

\begin{tabular}{lllll}
\hline & $\mathrm{N}^{*}$ & Crack-cocaine $^{* *}$ & & \\
Variable & $n(\%)$ & $n(\%)$ & OR c2 $[95 \% \mathrm{CI}]$ & $\mathrm{p}^{* * *}$ \\
\hline
\end{tabular}

Model 1

Gender

$\begin{array}{lllll}\text { Male } & 614(63.2) & 356(87.5) & 7.662[5.179,11.338] & <.0001 \\ \begin{array}{l}\text { Female } \\ \text { Age }\end{array} & 357(36.8) & 51(12.5) & 1.0[---] & \\ 18-29 & & & & \\ & 544(56.0) & 200(49.1) & 1.094[0.725,1.652] & .668\end{array}$




$\begin{array}{lllll}30-39 & 201(20.7) & 130(31.9) & 3.103[1.868,5.155] & <.0001 \\ \begin{array}{l}\text { 40- 59 } \\ \text { Schooling }\end{array} & 226(23.3) & 77(18.9) & 1.0[---] & \\ \text { Elementary School } & 150(15.4) & 104(25.6) & 9.381[2.909,30.257] & <.0001 \\ \text { High School } & 305(31.4) & 172(42.3) & 7.788[2.511,24.159] & <.0001 \\ \text { Undergraduate } & 478(49.2) & 125(30.7) & 2.232[0.728,6.839] & .160 \\ \text { Graduate } & 38(3.9) & 6(1.5) & 1.0[---] & \\ \text { Internalizing Symptoms } & & & & \\ \text { Normal } & 489(50.5) & 111(27.4) & 1.0[---] & <.0001 \\ \text { Borderline } & 170(17.6) & 79(19.5) & 2.800[1.805,4.344] & <.0001 \\ \text { Clinical } & 309(31.8) & 215(53.1) & 7.662[5.201,11.286] & \end{array}$

Model 2

Gender

\begin{tabular}{lllll} 
Male & $614(63.2)$ & $356(87.5)$ & $8.122[5.444,12.119]$ & $<.0001$ \\
Female & $357(36.8)$ & $51(12.5)$ & $10[---]$ & \\
Age & & & & \\
$18-29$ & $544(56.0)$ & $200(49.1)$ & $1.108[.733,1.675]$ & .625 \\
$30-39$ & $201(20.7)$ & $130(31.9)$ & $3.235[1.957,5.348]$ & $<.0001$ \\
$40-59$ & $226(23.3)$ & $77(18.9)$ & $1.0[---]$ & \\
Schooling & & & $10.491[3.167,34.755]$ & $<.0001$ \\
Elementary School & $150(15.4)$ & $104(25.6)$ & $9.695[3.037,30.950]$ & $<.0001$ \\
High School & $305(31.4)$ & $172(42.3)$ & $2.532[.804,7.982]$ & .113 \\
Undergraduate & $478(49.2)$ & $125(30.7)$ & $1.0[---]$ & \\
Graduate & $38(3.9)$ & $6(1.5)$ & $1.0[---]$ & \\
Anxiety/Depression & & & $4.716[2.929,7.593]$ & $<.0001$ \\
Normal & $679(70.1)$ & $200(49.4)$ & $10.186[6.055,17.134]$ & $<.0001$ \\
Borderline & $135(13.9)$ & $83(20.5)$ & $122(30.1)$ & \\
Clinical & $154(15.9)$ & 1.001 & \\
\hline
\end{tabular}

Note: ${ }^{\star}(N=971)$ Percentages obtained based on the total sample; ${ }^{*}(n=407)$ Percentages obtained based on the total values for each category of the variables listed for the regression model; $\mathrm{OR}=$ Odds Ratio; $\mathrm{CI}=$ Confidence interval. ${ }^{\text {a }}$ Parameters for model 1: Pseudo- $\mathrm{R}^{2}=0.513$; “-2 log Likelihood $=464.368$ (Step $1=465,526)$; Hosmer and Lemeshow $(p=.928)$; Pearson's chi-square $\left(c^{2}=464.368 ; p>.05\right) .{ }^{\mathrm{b}}$ Parameters for model 2: Pseudo- $\mathrm{R}^{2}=.494 ;$; $-2 \log$ Likelihood $=872.993$ (Step 1=867.888); Hosmer and Lemeshow ( $p=.365)$; Pearson's chi square $\left(c^{2}=14.694 ; p>.05\right)$.

According to the results shown in model 1, the externalizing symptoms, although statistically significant in univariate analysis, did not show statistical significance $(p>.20)$ in the multivariate model. Internalizing symptoms identified within the 
clinical range were defined as a significant predictive factor, with a 7.662 times higher risk of belonging to the group of drug users when compared to those within the normal range [95\% CI: 5.201, 11.286]. The risk (OR: 2.800) was also representative in the borderline range [95\% CI: 1.805, 4.344]. It should be stressed that the risk estimates are adjusted for the representative influence of being male, ranging from 30 to 39 years old and primary and secondary education.

In the second model, we considered the internalizing symptoms' subscales to define predictive factors for the group of crack-cocaine users. According to the results, the anxiety/depression subscale, with risks of 10.186 [95\% CI: 6.055, 17.134] and 4.716 [95\% CI: 2.929, 7.593] in the clinical and borderline ranges, respectively, compared to those within the normal range, was characterized as significant.

\section{DISCUSSION}

The results obtained in the present study show significant correlations between psychopathological aspects and the use of crack-cocaine. These findings demonstrate the importance of identifying comorbidities to ensure more effective diagnosis and treatment, contemplating other aspects involved in the use of psychoactive substances.

The study shows that crack-cocaine users are within the borderline and clinical range of internalizing symptoms when compared to the general population, which is within the normal range. Additionally, this result corroborates with Sayago, Lucena-Santos, Horta, and Oliveira's (2014) survey, in which they used a sample of crack-cocaine inpatients that showed a high prevalence of internalizing symptoms.

In the externalizing symptoms' comparison, the crack-cocaine group was related to a greater severity than the non-users group again. Hence, we can infer that this drug use is related to more aggressive behaviours and inadequate social characteristics. In another study, cocaine use was associated with some violent incident in $56.8 \%$ of the reports from users undergoing treatment (Macdonald et al., 2008). The findings of another study also indicate positive correlation $(p=.028)$ between crack-cocaine use and violent aggressive incidents (Narvaez et al., 2014).

The final adjusted model of crack-cocaine use severity indicates that age, gender, education, and the subscale of internalizing symptoms - anxiety/depression are related variables. Hence, we can infer that male young adults, with lower education and severe symptoms of anxiety/depression were related to the group of crack-cocaine users, thus these characteristics indicate a higher risk for use of this drug. This profile is similar to the profile of Brazilian crack-cocaine user addressed by the national survey developed by FIOCRUZ (Bastos \& Bertoni, 2014). The FIOCRUZ 
survey, as well as this survey, revealed that crack-cocaine users are represented by male young adults with low educational attainment.

The anxiety/depression symptoms reinforce the idea that these symptoms may predict drug-seeking behaviours. A similar finding was obtained by the logistic regression done in the study Buckner, Proctor, Reynolds, Kopetz, and Lejuez (2011) study, which correlated anxiety and cocaine addiction.

It should be stressed that the externalizing symptoms variable was not adjusted to the model as expected in the theory (Macdonald et al., 2008; Narvaez, et al., 2014). This result may indicate that inpatients admitted for rehabilitation trend to accept help and therefore usually don't act very impulsively. Another issue is where the collection took place, because in prisons or similar locations, this variable would be probably more prevalent.

One limitation of the study was the use of only one instrument in data collection, which limited the interpretations, since the ASR assesses the last six months of the respondent's life, which only allows inferences regarding post-drug use characteristics. Furthermore, we did not use any additional instrument to assess drug use, aside from the ASR questions and the fact that the participants from the clinical group were already identified. This did not allow comparisons addressing the use of other drugs.

Another limitation was the use of a self-report, which might impinge the results, although it should be stressed that the chosen instrument is safe and demonstrated internal consistency in Brazilian surveys with a similar population (Lucena-Santos et al., 2014).

We suggest for further studies the use of other resources, such as family reports and/or reports from people connected to the participant. Likewise, we suggest other study designs, such as longitudinal, which can assess the subject for a period of time.

Results addressing the significant connection between psychopathological aspects and crack-cocaine use, mainly the positive correlation between anxiety and depression symptoms, support the idea that these symptoms might predict drug-seeking behaviours. Therefore, they highlight the importance of identifying comorbidities so that the diagnosis and treatment are more effective, comprehending other aspects of the psychoactive substance use.

\section{ACKNOWLEDGMENTS}

To Alan Saloum Bastos for his dedication. 


\section{REFERENCES}

Achenbach, T. M., \& Rescorla, L. A. (2003). Manual for the ASEBA adult form \& profiles. Burlington, VT: University of Vermont, Research Center for Children, Youth \& Families.

Bastos, F. I., \& Bertoni, N. (Org.). (2014). Pesquisa nacional sobre o uso de crack: Quem são os usuários de crack elou similares do Brasil? Quantos são nas capitais brasileiras? Rio de Janeiro: Editora ICICT/FIOCRUZ.

Bolsoni-Silva, A. T., \& Marturano, E. M. (2010). Evaluation of group intervention for mothers/caretakers of kindergarten children with externalizing behavioral problems. Interamerican Journal Psychology, 44(3), 415-421.

Buckner, J. D., Proctor, S. L., Reynolds, E., Kopetz, C., \& Lejuez, C. W. (2011). Cocaine dependence and anxiety sensitivity among patients presenting for residential drug use treatment. Journal of Cognitive Psychotherapy, 25(1), 22-30. doi: 10.1891/0889-8391.25.1.22

Cepeda, M. S., Boston, R., Farrar, J. T., \& Strom, B. L. (2003). Comparison of logistic regression versus propensity score when the number of events is low and there are multiple confounders. American Journal of Epidemiology, 158(3), 280-287. doi: 10.1093/aje/kwg115

Chen, K. W., Banduccia, A. N., Guller, L., Macatee, R. J., Lavellec, A., Daughtersc, S. B., \& Lejuez, C. W. (2011). An examination of psychiatric comorbidities as a function of gender and substance type within an inpatient substance use treatment program. Drug and Alcohol Dependence, 118(2-3), 92-99. doi:10.1016/j.drugalcdep.2011.03.003

Johnson, J. E., O’Leary, C. C., Striley, C. W., Abdallah, A. B., Bradford, S., \& Cottler, L. B. (2011). Effects of major depression on crack use and arrests among women in drug court. Addiction, 106(7), 1279-1286. doi:10.1111/j.1360-0443.2011.03389.x

Laranjeira, R. (Org.). (2014). II Levantamento Nacional de Álcool e Drogas, II LENAD. São Paulo: Instituto Nacional de Ciência e Tecnologia para Políticas Públicas de Álcool e Outras Drogas (INPAD), UNIFESP. Consultado em http://inpad.org.br/wp-content/uploads/2014/03/Lenad-II-Relat\%C3\%B3rio.pdf

Lucena-Santos, P., Moraes, J. F. D., \& Oliveira, M. S. (2014). Analysis of the factor structure of syndromes scales of ASR (Adult Self-Report). Interamerican Journal of Psychology, 48(2), 252-264.

Macdonald, S., Erickson, P., Wells, S., Hathaway, A., \& Pakula, B. (2008). Predicting violence among cocaine, cannabis, and alcohol treatment clients. Addictive Behaviors, 33(1), 201-205. doi:10.1016/j.addbeh.2007.07.002

Marmorstein, N. (2012). Anxiety disorders and substance use disorders: Different associations by anxiety disorder. Journal of Anxiety Disorders, 26(1), 88-94. doi:10.1016/j.janxdis.2011.09.005

Medronho, R. A. (2003). Epidemiologia. São Paulo: Atheneu.

Narvaez, J. C. M., Jansen, K., Pinheiro, R. T., Kapczinski, F., Silva, R. A., Pechansky F., \& Magalhães, P. V. S. (2014). Violent and sexual behaviors and lifetime use of crack cocaine: A populationbased study in Brazil. Social Psychiatry and Psychiatric Epidemiology, 49(8),1249-1255. doi 10.1007/s00127-014-0830-3

Ribeiro, L. A., Nappo, S. A., \& Sanchez, Z. V. M. (2012). Aspectos socioculturais do consumo de crack. In M. Ribeiro \& R. Laranjeira (Orgs.), O tratamento do usuário de crack (pp. 50-56). Porto Alegre: Artmed.

Sayago, C. B., Lucena-Santos, P. L., Horta, L. R., \& Oliveira, M. S. (2014). Perfil clínico e cognitivo de usuários de crack internados. Psicologia: Reflexão e Crítica, 27(1), 21-28. doi: 10.1590/ S0102-79722014000100003 
Scheffer, M., Pasa, G. G., \& Almeida, R. M. M. (2010). Dependência de álcool, cocaína e crack e transtornos psiquiátricos. Psicologia: Teoria e Pesquisa, 26(3), 533-541. doi: 10.1590/S010237722010000300016

Silva, C. R., Kolling, N. M., Carvalho, J. C. N., Cunha, M. S., \& Kristensen, C. H. (2009). Comorbidade psiquiátrica em dependentes de cocaína/crack e alcoolistas: Um estudo exploratório. Aletheia, 30, 101-112.

UNODC, United Nations Office on Drugs and Crime. (2013). World Drug Report. United States: United Nations publication.

Vergara-Moragues, E., González-Saiz, F., Lozano-Rojas, O., Calderón, F. F., García, A. V., Espinosa, P. B., ... García, M. P. (2013). Relación entre la comorbilidad psicopatológica y las variables de resultados en dependientes de cocaína tratados en comunidad terapêutica. Adicciones, 25(2), 128-136. 